\title{
Androgen receptor expression is a significant prognostic factor in estrogen receptor positive
}

breast cancers

Isabella Castellano ${ }^{1}$, Elena Allia ${ }^{1}$, Valeria Accortanzo ${ }^{2}$, Anna Maria Vandone ${ }^{3}$, Luigi Chiusa ${ }^{1}$,

Riccardo Arisio ${ }^{4}$, Antonio Durando ${ }^{2}$, Michela Donadio ${ }^{3}$, Gianni Bussolati ${ }^{1}$, Alan S. Coates ${ }^{5-6}$, Giuseppe Viale $^{7}$, Anna Sapino ${ }^{1}$

(1) Department of Biomedical Sciences and Human Oncology, University of Turin, Turin, Italy.

(2) Department of Obstetrics and Gynaecology, Sant'Anna Hospital, Turin, Italy

(3) Centro Oncologico Subalpino (COES), Molinette Hospital, Turin, Italy

(4) Department of Pathology, Sant' Anna Hospital, Turin, Italy

(5) International Breast Cancer Study Group, Bern, Switzerland

(6) School of Public Health, University of Sydney, Sydney, Australia

(7) Division of Pathology and Laboratory Medicine, European Institute of Oncology, University of Milan, Milan.

Corresponding author: Anna Sapino, MD

Department of Biomedical Sciences and Human Oncology

Via Santena 7, 10126, Torino

Te100390116334127

Fax 00390116635267

Email: anna.sapino@unito.it 


\section{Abstract}

Purpose To evaluate the prognostic value of androgen receptor (AR) expression in patients with estrogen receptor (ER)-positive breast cancer treated with endocrine therapy with or without the addition of chemotherapy.

Patients and Methods A consecutive series of 953 patients with ER-positive breast cancer treated between 1998 and 2003 was selected. Repeated immunohistochemistry confirmed the expression of ER in the tumor of 938 patients. AR expression was measured by immunohistochemistry. The Kaplan-Meier method, logrank test and multivariate Cox models were used to explore the impact of AR expression on time to relapse (TTR) and disease specific survival (DSS) in all patients and in subgroups treated with chemo-endocrine therapy or endocrine therapy alone. Results AR immunoreactivity was assessable in 859 tumors and positive in 609 (70.9\%). AR expression was a significant marker of good prognosis for TTR $(P=0.001)$ and DSS $(P<0.001)$. This effect was particularly evident in the group of patients receiving chemo-endocrine therapy (TTR $(P=0.015)$ and DSS $(P<0.001))$. Cox models confirmed AR as an independent variable for both TTR $(P=0.003$, HR $0.444,95 \%$ CI $0.258-0.765)$ and DSS $(P<0.001$, HR $0.135,95 \%$ CI $0.054-0.337)$. Thus, we focused on ER positive luminal B breast cancer that may be selected for chemotherapy because of their more aggressive immunophenotype. In this subset AR expression identified a group of patients with better prognosis for TTR $(P=0.017$, HR $0.521,95 \%$ CI $0.306-0.888)$ and DSS $(P=0.001$, HR 0.276 , 95\% CI 0.130- 0.588). Conclusion AR expression is an independent prognostic factor of better outcome in patients with ER-positive breast cancers

Keywords: Androgen receptor, prognosis, estrogen receptor, breast cancer, chemotherapy. 


\section{Introduction}

Increasing data support a possible role of the androgen receptor (AR) as a marker of prognosis [1,2], particularly among patients with estrogen receptor (ER) positive breast cancer [3]. AR are frequently expressed together with ER and progesterone receptor $(\mathrm{PgR})$ in well diffe rentiated breast cancer [4-6], but are rarely present in human epidermal growth factor receptor 2 (HER2) positive tumors [7,8]. Specific cancer histotypes, such as the apocrine carcinoma consistently express AR [9-10] despite being ER and PgR-negative, and AR expression has been reported in about $45 \%$ of triple negative breast cancers $[4,8]$. Studies using different analytical procedures such as a binding assay [11], immunohistochemistry (IHC) [3,12] and reverse-phase protein arrays [13] have suggested a possible role of AR to predict responsiveness to endocrine therapy. The impact of AR expression on survival of patients with high risk ER-positive breast cancer, such as luminal B breast cancer [14-16], has never been evaluated. However, it has been shown that in metastatic breast cancers, the median survival after disease recurrence of patients with AR-expressing tumors was significantly longer compared to that of patients with AR-negative tumors [2].

In this study, we evaluated the prognostic value of AR in a large series of patients with ER positive breast cancer after long follow-up. All patients were treated with endocrine therapy, with or without addition of chemotherapy. In particular, we focused on a subset of patients with tumors closely similar to luminal type B by conventional markers [17] and considered as more clinically aggressive than the luminal type A ER-positive breast cancers.

\section{Patients and methods}

Study design

A consecutive series of 953 patients diagnosed with ER-positive breast cancer between 1998 and 2003 was retrieved from the files of the Pathology Departments of the San Giovanni Battista- 
Molinette Hospital (431 cases) and S. Anna Hospital (522 cases) in Turin, Italy. Tumor slides were centrally reviewed by two of the authors (AS, IC). Representative blocks were obtained and multicore tissue microarrays (TMAs) were prepared, as previously described [18], using the advanced tissue arrayer (mod ATA-100, Chemicon International, Tamecula, CA, USA). Sections of the resulting recipient blocks were retested by IHC for ER status. Fifteen of 953 tumors were deemed ER-negative on TMAs and the negative results were further confirmed on whole tissue sections. These cases were excluded from the study (Fig. 1). Clinical data of the remaining 938 patients including age, type of surgery, type of treatment, occurrence and type of relapse and current status were obtained from the Oncology Department of the two institutions. To confirm accuracy of previously recorded data, medical charts of all patients were reviewed. Pathological data including histotype, grade, and size of the tumors, peritumoral vascular invasion and stage were recorded according to the original diagnosis. The study was conducted in compliance with the ethical regulatory issues of the participating institutions.

Immunohistochemical procedure

IHC was performed using an automated slide processing platform (Ventana BenchMark AutoStainer, Ventana Medical Systems, Tucson, AZ, USA) and the following primary antibodies: prediluted anti-ER rabbit monoclonal antibody (SP1, Ventana-Diapath, Tucson, AZ, USA); prediluted anti-PgR rabbit monoclonal antibody (1E2, Ventana-Diapath); anti-AR mouse monoclonal antibody (AR441, diluted 1:50, Dako, Glostrup, Denmark); anti-Ki67 monoclonal antibody (MIB1, diluted 1:100 Dako) and anti-HER2 polyclonal antibody (A0485, diluted 1:800, Dako). FISH assays for assessing HER2 gene amplification were performed for IHC equivocal (score 2+) cases, as previously reported [19].

Positive and negative controls (omission of the primary antibody and IgG-matched serum) were included for each immunohistochemical run. 
All TMAs slides were scanned by the Aperio system (ScanScope CS System, Vista, Ca, USA) and automated counting was performed. To ensure the reliability of the automatic assessment all cases were reviewed on screen by two of the authors (A.S. and I.C.) blinded to patients' treatment assignment or outcome. If the recorded percentage of immunostained cells differed by more than $10 \%$, then a collegial re-evaluation of the results was performed by three pathologists at the multiheaded microscope (I.C., R.A. and A.S.). This occurred for $1.2 \%$ of tumors. According to previous studies the cut off value for ER and PgR positivity was set at $\geq 1 \%$ and the same cut-off was also adopted for AR positivity [20]. The percentage of Ki67-positive cells was recorded and the cut-off for dichotomizing tumors with low and high proliferative fraction was established at $10 \%$ positive cells for the overall study population, and at $14 \%$ for sorting out luminal type B breast cancer as suggested by Cheang MC et al [17]. HER2 status was classified as negative or positive (when scored $3+$ by IHC or HER 2 amplified by FISH) according to the recommended guidelines for invasive carcinoma [21].

Statistical Analysis

Differences between AR positive versus AR negative tumors were analyzed by univariate analysis with the Chi-square or Fisher's exact test: $P$-values $<0.05$ were considered to be statistically significant.

Median follow-up time was calculated as the median observation time among all patients. Follow- up was censored at the time of death or the last clinical investigation of the patient.

Disease-specific survival (DSS) was calculated from the data of definitive surgery to the date of death of disease. Patients dying from other causes were censored at the time of death. Time to relapse (TTR) was measured from the data of definitive surgery to the data of first recurrence (defined as loco-regional or systemic). Contralateral breast cancer was not considered as relapse. 
The Kaplan-Meier method was used to estimate the TTR and DSS. The logrank test was used to test the survival differences.

Univariate analysis was used to examine what variables were associated with prognosis. Variables of interest included: age, histotype, histological grade, $\mathrm{pT}$ and $\mathrm{pN}$ staging, vascular invasion, type of surgery (mastectomy versus breast conserving surgery), radiotherapy and chemotherapy. In order to adjust the risk estimate for potential confounders, a Cox proportional hazard regression for DSS and TTR was used and hazard ratios (HR) were calculated. Multivariate analysis included variables significant at $P<0.05$ in univariate models or with a priori hypothesis for inclusion.

Statistical analysis was carried out using the SPSS version 17 (SPSS Inc, Chicago, IL) software, the R environment [www.r-project.org], SAS version 9.1 (SAS Institute, Cary, NC) and S-PLUS version 6.1 (Insightful Corp, Seattle, WA). This article was written in accordance with Reporting Recommendations for Tumor Marker Prognostic Studies guidelines [22].

\section{Results}

Patients' characteristics

The study cohort included 938 patients with tumors confirmed as ER positive. Clinical and histopathological features of the whole population are reported in Table 1. The median follow-up time was 6.8 years.

All patients were treated with endocrine therapy. The majority received tamoxifen as first option, 180 patients switched from tamoxifen to an aromatase inhibitor after 2 years. Using the local protocol (Online Resource 1) defined during the time period of this study (patient's age $<50$ years and tumor $>2 \mathrm{~cm}$ in size and/or presence of lymph node metastases and/or presence of peritumoral vascular invasion), a cohort of 390 patients received both endocrine and chemotherapy. 
Androgen receptor expression and outcome

AR was assessable in 859 tumors and $609(70.9 \%)$ of these were considered positive. As shown in Table 2, AR positivity was associated with small tumor size $(<2 \mathrm{~cm})$, absence of lymph node metastases and PgR expression. Of the 250 AR-negative cases, 137 (54.8\%) were treated with endocrine therapy only and $113(45.2 \%)$ with endocrine and chemotherapy; of the 609 AR positive cases $358(58.7 \%)$ were treated with endocrine therapy only and $251(41.2 \%)$ with endocrine and chemotherapy.

Univariate analysis performed on the whole cohort of patients confirmed the correlation of the traditional histological and immunophenotypical factors with TTR (Table 3) and DSS (Table 4). Focusing on AR expression, 609 patients with AR-positive tumors had a better outcome (Fig. $2 \mathrm{a}$ and 2b) (TTR: $P=0.001$ and DSS: $P<0.001$ ). Then we evaluated the effect of AR expression in the subcohort of patients treated with endocrine therapy alone. In this subset the $P$-value of AR positivity was marginally significant at 0.046 for TTR (Table 3 ) and not significant for DSS $(P=0.247$; Table 4; Fig. 3a). By contrast, in the group of patients receiving endocrine and chemotherapy, AR positivity was a strong prognostic factor for both TTR $(P=0.015$; Table 3$)$ and DSS $(\mathrm{P}<0.001$; Table 4, Fig. 3b). Following this result, we evaluated the effect of AR according to the different chemotherapeutic regimens, and we observed that AR expression was a marker of good prognosis in the group of patients treated with cyclophosphamide, methotrexate, and fluorouracil (CMF) $(P=0.001)$ and anthracycline $(P=0.018)$ (Fig. 3c and 3d). While no such significance was demonstrated among subsets of patients receiving other types of chemotherapy the numbers were limited and the data do not establish a reliable difference.

Cox multivariate analysis applied on the whole series of ER-positive cases for both TTR and DSS confirmed that AR status was an independent prognostic factor (Table 5). The same role of AR was observed at Cox analysis for TTR, but not for DSS in patients treated with endocrine 
therapy alone (Table 6), while AR remained an independent factor of good prognosis for both TTR and DSS in the group of patients treated with endocrine and chemotherapy, as did PgR and HER2 (Table 7). However, a formal test for interaction between the use of chemotherapy and the expression of AR was not significant either for TTR $(P=0.66)$ or DSS $(P=0.21)$ (Fig. 4), so this apparent difference needs to be interpreted with caution.

Androgen receptor expression and outcome in luminal type B breast cancer

To further explore the prognostic value of AR in ER-positive breast cancer with more aggressive biology that may be the target of chemotherapy, we selected a series of 343 cases classified on the basis of immunohistochemical markers as closely similar to the genetically defined Luminal B, as recently proposed by Cheang M.C. et al [17]. Briefly, we considered as Luminal B HER2 positive tumors and HER2 negative tumors with Ki67 >14\%. Comparison of DSS and TTR of luminal type B against luminal A tumors confirmed poorer outcome among patients classified as Luminal B (Fig. 3e). Univariate analysis showed that the prognostic value on DSS of AR was maintained within the luminal B tumors (Fig. 3f) and Cox analysis confirmed this result for AR together with age, tumor size, vascular invasion and chemotherapy (Table 8).

\section{Discussion}

In the present study on a large series of ER-positive breast cancers, AR expression, as evaluated by IHC, provides statistically significant prognostic value beyond established clinicopathological parameters.

The role of AR as a prognostic marker has been suggested by other authors, though there is a high variability in patient populations, assay methods, analysis of results, definitions used and reporting of results $[3,10-12,23]$. Particularly, the IHC cut-off values for positive and negative AR status are quite variable within different studies [3,8] or are not reported at all [12]. In the present 
study we used an automated system of analysis of IHC reactions that should avoid the bias of subjectivity linked to quantitative evaluation of IHC markers as performed by traditional microscopy. Using a cut off of $\geq 1 \%$, the AR expression rate in ER-positive breast cancer was of almost $71 \%$, which is comparable with previous reports on breast cancer in general $[4,8]$. If the cutoff was increased to $\geq 10 \%$, the prevalence of positive cases would decrease to $60 \%$, though the significant correlation with outcome is maintained (Online Resource 2). A possible bias of the present work might be the use of TMAs, but using the multicore procedure we have previously shown that hormone receptors -and in particular ER levels- are correctly evaluated without significant discrepancy as compared to whole section analysis [18].

In addition, we showed that positive AR expression by IHC identifies patients with better prognosis within the subset of luminal type B tumors. Gene expression studies have identified two molecularly distinct subtypes of ER-positive breast cancers, the luminal types A and B, with luminal B tumors having poorer outcomes than luminal A tumors [14-16]. Recent studies have suggested that a combination of conventional IHC markers [17] may be considered a suitable surrogate for identifying a subset of breast cancers closely similar to the luminal B type defined by gene expression analysis. Our results show that in luminal type B cancers AR expression could be used as a prognostic marker, selecting a group of AR-positive tumors with better prognosis.

The likelihood of response of ER-positive breast cancers to adjuvant systemic chemotherapy cannot be accurately predicted, and the results of our retrospective study do not allow any conclusion that AR expression can predict which patients will benefit from the addition of chemotherapy, or indeed any particular type of chemotherapy, though the information that overall risk of relapse is lower in patients whose tumors express AR may assist decision-making in some cases. However, a recent study of triple negative breast cancers has shown by in vitro ATP-based chemotherapy response assay (ATP-CRA) that chemosensitivity to 5-fluorouracil and methotrexate was higher for tumors expressing AR and that this effect was not observed with other chemotherapeutics, such docetaxel, doxorubicin, epirubicin, vinorelbine, gemcitabine, oxaliplatin 
and paclitaxel [24]. Although a statistically significant interaction between chemotherapy and the expression of AR was not demonstrated, our results confirmed both by uni- and multivariate analysis a significant correlation of AR positive immunoreaction and longer DSS in patients treated with any chemotherapeutic regimen containing CMF and also with regimens containing an anthracycline, while there was not a significant correlation of AR with survival in patients treated with taxanes or vinorelbine. On the other hand, recent experimental data suggest a role for AR overexpression as a novel mechanism of tamoxifen resistance and speculate that AR and ER could collaborate to regulate cyclin D1 gene expression, thereby promoting cell cycle progression in the presence of tamoxifen [25]. Taken together these data may suggest that AR/ER positive breast cancer with high Ki67 expression could resist to tamoxifen therapy and benefit from specific chemotherapeutic treatment containing CMF and/or anthracyclines. Specific clinical trials and independent data set of patients with ER positive disease who received chemo-endocrine therapy are needed to confirm this hypothesis.

The 2009 St. Gallen recommendations consider endocrine therapy indicated if any ER staining is present in the tumor [26]. One of the most difficult challenges in treating these patients, however, is the identification of patients with incompletely endocrine-responsive tumor who should receive a chemo-endocrine treatment. In prostate cancer, it has been suggested that knowledge of AR action in promoting cell proliferation can be used to design strategies that maximize cell death in response to cytotoxic therapy [27]. The results of the present study suggest that AR could be an important parameter for designing specific systemic treatments for the patients with ER-positive breast cancer. 
Acknowledgments of research support for the study: This study was funded by Compagnia San Paolo di Torino, Cassa di Risparmio di Torino, AIRC 2007-2009, Ricerca Finalizzata Regione Piemonte 2008. 


\section{References}

1. Rakha EA, El-Sayed ME, Green AR et al (2007) Prognostic markers in triple-negative breast cancer. Cancer 109: 25-32

2. Schippinger W, Regitnig P, Dandachi N et al (2006) Evaluation of the prognostic significance of androgen receptor expression in metastatic breast cancer. Virchows Arch 449:24-30

3. Peters AA, Buchanan G, Ricciardelli C et al (2009) Androgen receptor inhibits estrogen receptor-alfa activity and is prognostic in breast cancer. Cancer Res 69: 6131-6140

4. Moinfar F, Okcu M, Tsybrovskyy O et al (2003) Androgen receptors frequently are expressed in breast carcinomas: Potential re levance to new therapeutic strategies. Cancer 98:703-711

5. Kuenen-Boumeester V,Van der Kwast TH, Claassen CC et al (1996) The clinical significance of androgen receptors in breast cancer and the ir relation to histological and cell biological parameters. Eur J Cancer 32A:1560-1565

6. Sapino A, Righi L, Cassoni P et al (2001) Expression of apocrine differentiation markers in neuroendocrine breast carcinomas of aged women. Mod Pathol 14:768-776

7. Kollara A, Kahn HJ, Marks A et al (2001) Loss of androgen receptor associated protein 70 (ARA70) expression in a subset of HER2-positive breast cancers. Breast Cancer Res Treat 67:245-253

8. Ogawa Y, Hai E, Matsumoto K et al (2008) Androgen receptor expression in breast cancer: relationship with clinicopathological factors and biomarkers. Int J Clin Oncol 13:431-435

9. Gatalica Z (1997) Immunohistochemical analysis of apocrine breast lesions. Consistent overexpression of androgen receptor accompanied by the loss of estrogen and progesterone receptors in apocrine metaplasia and apocrine carcinoma in situ. Pathol Res Pract 193:753-758

10. Niemeier LA, Dabbs DJ, Beriwal S et al (2009) Androgen receptor in breast cancer: expression in estrogen receptor-positive tumors and in estrogen receptor-negative tumors with apocrine differentiation. Mod Pathol Doi: 10.1038/modpathol.2009.159 
11. Bryan RM, Mercer RJ, Bennett RC et al (1984) Androgen receptors in breast cancer. Cancer $54: 2436-2440$

12. Agrawal AK, Jeleń M, Grzebieniak Z et al (2008) Androgen receptors as a prognostic and predictive factor in breast cancer. Folia Histochem Cytobiol 46:269-276

13. Gonzalez-Angulo AM, Stemke-Hale K, Palla SL et al (2009) Androgen receptor levels and association with PIK3CA mutations and prognosis in breast cancer. Clin Cancer Res 15:2472-2478 14. Sorlie T, Perou CM, Tibshirani R et al (2001) Gene expression patterns of breast carcinomas distinguish tumor subclasses with clinical implications. Proc Natl Acad Sci USA 98:10869-10874 15. Perou CM, Sorlie T, Eisen MB et al (2000) Molecular portraits of human breast tumours. Nature 406:747-752

16. Sorlie T, Tibshirani R, Parker J et al (2003) Repeated observation of breast tumor subtypes in independent gene expression data sets. Proc Natl Acad Sci USA 100:8418-8423

17. Cheang MC, Chia SK, Voduc D et al (2009) Ki67 index, HER2 status, and prognosis of patients with luminal B breast cancer. J Natl Cancer Inst 101:736-750

18. Sapino A, Marchiò C, Senetta R et al (2006) Routine assessment of prognostic factors in breast cancer using a multicore tissue microarray procedure. Virchows Arch 449:288-296

19. Marchiò C, Lambros MB, Gugliotta $\mathrm{P}$ et al (2009) Does chromosome 17 centromere copy number predict polysomy in breast cancer? A fluorescence in situ hybridization and microarray-based CGH analysis. J Pathol 219:16-24

20. Liu S, Chia SK, Mehl E et al (2010): Progesterone receptor is a significant factor associated with clinical outcomes and effect of adjuvant tamoxifen therapy in breast cancer patients. Breast Cancer Res Treat 119:53-61

21. Wolff AC, Hammond ME, Schwartz JN et al (2007) American Society of Clinical Oncology/College of American Pathologists guideline recommendations for human epidermal growth factor receptor 2 testing in breast cancer. J Clin Oncol 25:118-145 
22. McShane LM, Altman DG, Sauerbrei W et al (2006) REporting recommendations for tumor MARKer prognostic studies (REMARK). Brest Cancer Res treat 100: 229-235

23. Park S, Koo J, Park HS et al (2009) Expression of androgen receptors in primary breast cancer. Ann Oncol. Doi:10.1093/annonc/mdp510

24. Koo JS, Jung W, Jeong J (2009): The Predictive Role of E-cadherin and Androgen Receptor on In Vitro Chemosensitivity in Triple-negative Breast Cancer. Jpn J Clin Oncol 39:560-568

25. De Amicis F, Thrugnansampanthan J, Cui Y et al (2009) Androgen receptor overexpression induces tamoxifen resistance in human breast cancer cells. Breast Cancer Res Treat. Doi: $10.1007 / \mathrm{s} 10549-009-0436-8$

26. Goldhirsch A, Ingle JN, Gelber RD et al (2009) Thresholds for therapies: highlights of the St Gallen International Expert Consensus on the Primary Therapy of Early Breast Cancer 2009. Ann Oncol 20: 1319-1329

27. Hess-Wilson JK, Daly HK, Zagorski WA et al (2006) Mitogenic action of the androgen receptor sensitizes prostate cancer cells to taxane-based cytotoxic insult. Cancer Res 66:11998-12008 


\section{Figure Legends}

Fig. 1 Study flowchart shows the process for patient selection

$E R$ Estrogen Receptor; TMA tissue micro array.

Fig. 2 Kaplan-Meier estimates of (a) time to relapse and (b) disease specific survival according to androgen receptor in 859 ER-positive breast tumors

Fig. 3 Kaplan-Meier estimates of disease specific survival according to and rogen receptor in patients treated by (a) endocrine therapy, (b) endocrine and chemotherapy, (c) Cyclophosphamide, Methotrexate and Fluorouracil (CMF) and (d) Anthracyclines. Kaplan-Meier estimates of disease specific survival according to (e) luminal types of breast cancers and according to (f) androgen receptor in luminal B cases

$A R$. Androgen Receptor; $D S S$. disease specific survival; $C I$. confidence interval

Fig. 4 Proportional hazard model results of Cox analysis in the whole ER-positive cohort and in the endocrine treated and endocrine and chemo-treated subgroups $H R$. hazard ratio; $C I$ confidence interval. 


\section{Suppleme ntary material}

\section{Online resource 1: Age and pathological data according to chemotherapy (CT) treatment}

Article title: Androgen receptor expression is a significant prognostic factor in estrogen receptor positive breast cancers

Journal name: Breast Cancer Research and Treatment

Author names: Isabella Castellano, Elena Allia, Valeria Accortanzo, Anna Maria Vandone, Luigi

Chiusa, Riccardo Arisio, Antonio Durando, Michela Donadio, Gianni Bussolati, Alan S. Coates, Giuseppe Viale, Anna Sapino

Affiliation and e-mail address of the corresponding author:

Anna Sapino, MD, Department of Biomedical Sciences and Human Oncology

Via Santena 7, 10126, Torino

Email: $\underline{\text { anna.sapino@unito.it }}$

Online resource 2: Kaplan-Meier estimates of time to relapse (a) and disease specific survival (b) in 859 patients according to androgen receptor cut off of $10 \%$

AR: Androgen Receptor; DSS: disease specific survival; TTR: time to relapse; CI: confidence interval

Article title: Androgen receptor expression is a significant prognostic factor in estrogen receptor positive breast cancers

Journal name: Breast Cancer Research and Treatment

Author names: Isabella Castellano, Elena Allia, Valeria Accortanzo, Anna Maria Vandone, Luigi Chiusa, Riccardo Arisio, Antonio Durando, Michela Donadio, Gianni Bussolati, Alan S. Coates, Giuseppe Viale, Anna Sapino

Affiliation and e-mail address of the corresponding author:

Anna Sapino, MD, Department of Biomedical Sciences and Human Oncology

Via Santena 7, 10126, Torino

Email: $\underline{\text { anna.sapino@unito.it }}$ 


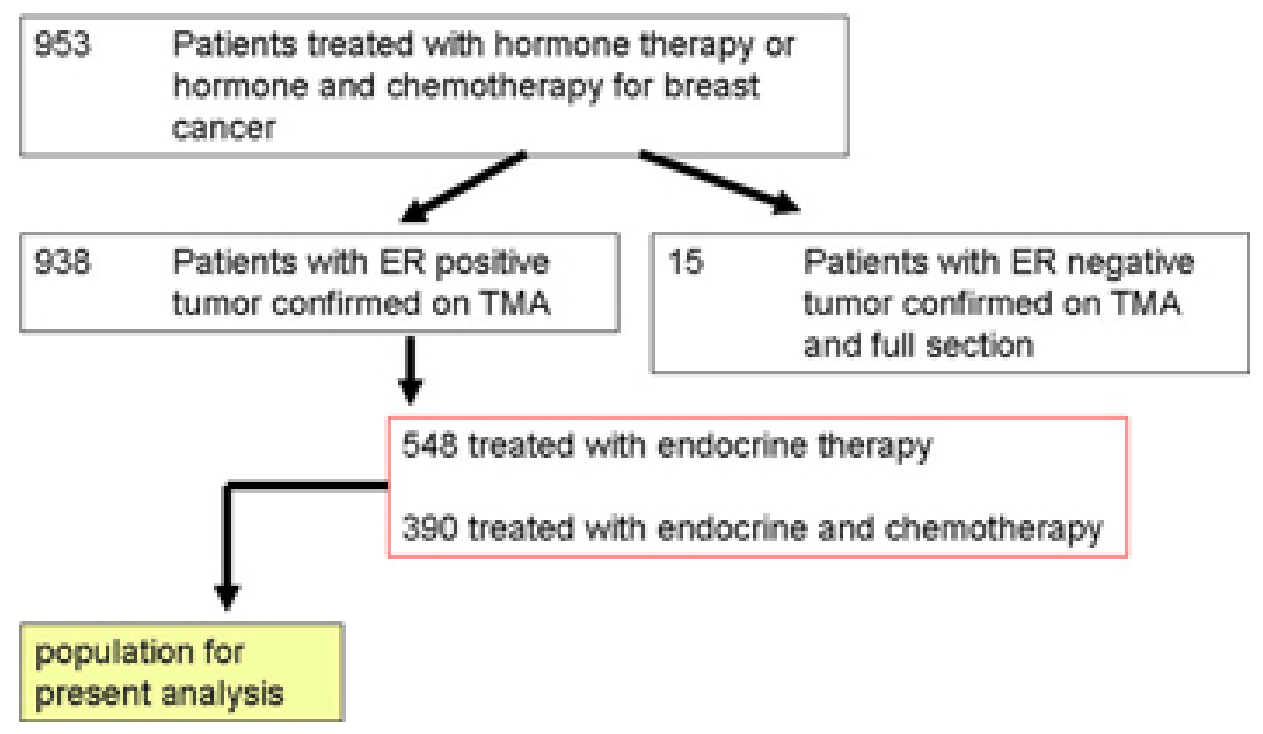




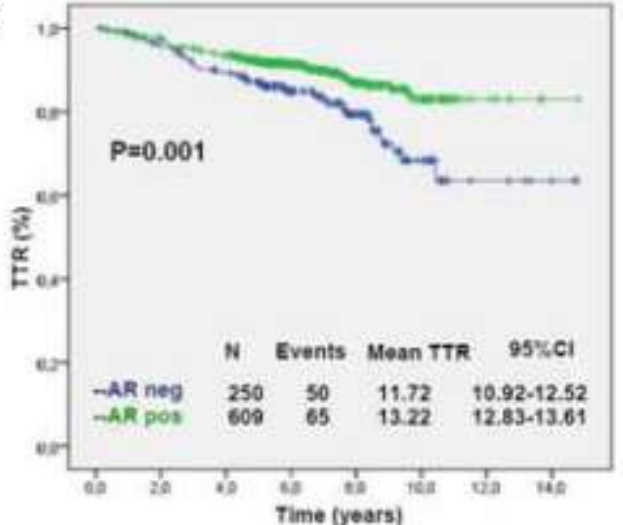

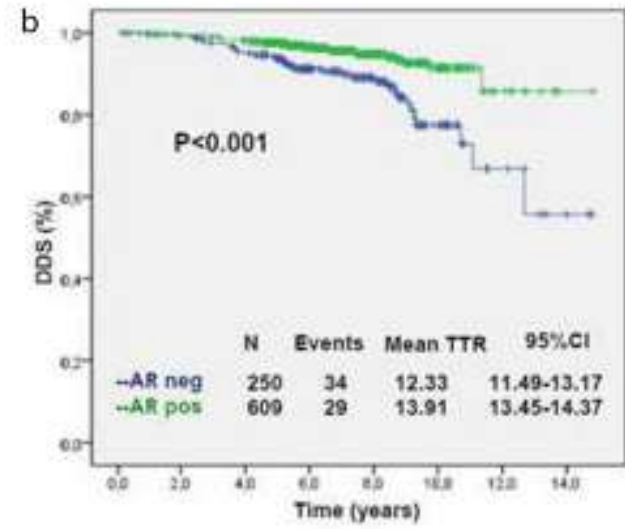



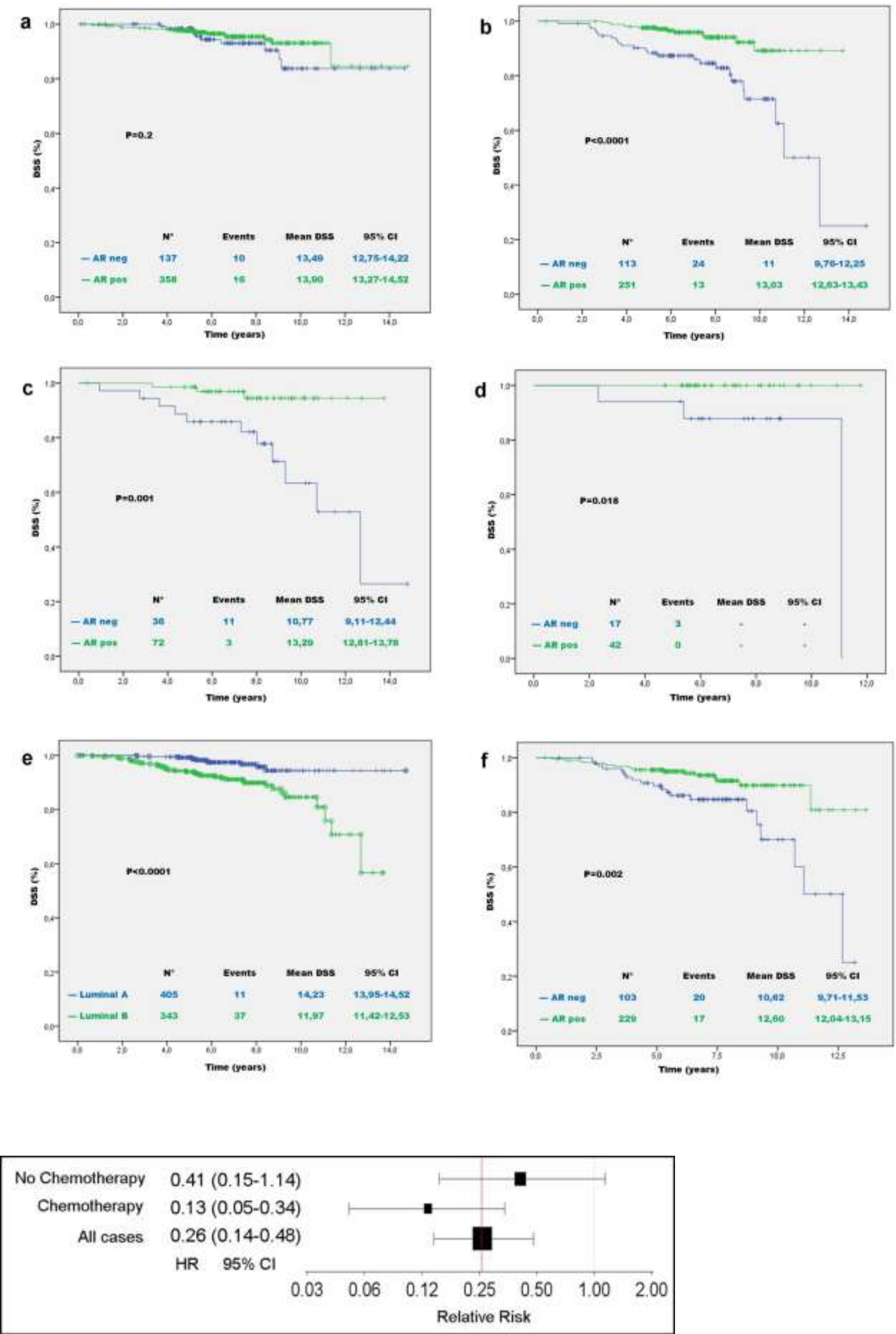
Table 1 Clinical and histopathological characteristics of 938 estrogen receptor positive breast cancers

\begin{tabular}{|c|c|c|c|}
\hline & $\begin{array}{l}\text { Number } \\
\text { of cases }\end{array}$ & Total \% & Valide $\%$ \\
\hline $\begin{array}{ll}\text { Age } & \\
& \leq 40 \text { years } \\
& 40-70 \text { years } \\
& \geq 70 \text { years }\end{array}$ & $\begin{array}{c}31 \\
717 \\
190 \\
\end{array}$ & $\begin{array}{c}3.3 \\
76.4 \\
20.3 \\
\end{array}$ & $\begin{array}{c}3.3 \\
76.4 \\
20.3 \\
\end{array}$ \\
\hline $\begin{array}{rr}\text { Relapse Type } & \text { No } \\
\text { Local } \\
\text { Systemic } \\
\text { Controlateral }\end{array}$ & $\begin{array}{l}791 \\
35 \\
90 \\
22\end{array}$ & $\begin{array}{l}84.3 \\
3.7 \\
9.6 \\
2.3\end{array}$ & $\begin{array}{l}84.3 \\
3.7 \\
9.6 \\
2.3\end{array}$ \\
\hline $\begin{array}{rr}\text { Death of disease } & \\
& \text { No } \\
\text { Yes } \\
\end{array}$ & $\begin{array}{c}868 \\
70 \\
\end{array}$ & $\begin{array}{c}92.5 \\
7.5 \\
\end{array}$ & $\begin{array}{c}92.5 \\
7,5 \\
\end{array}$ \\
\hline $\begin{array}{r}\text { Histotype } \\
\qquad \begin{array}{r}\text { Ductal and Lobular } \\
\text { Special types }\end{array}\end{array}$ & $\begin{array}{l}638 \\
300 \\
\end{array}$ & $\begin{array}{l}68.0 \\
31.9 \\
\end{array}$ & $\begin{array}{l}68.0 \\
31.9 \\
\end{array}$ \\
\hline Grade & $\begin{array}{l}315 \\
406 \\
217 \\
\end{array}$ & $\begin{array}{l}33.6 \\
43.3 \\
23.1 \\
\end{array}$ & $\begin{array}{l}33.6 \\
43.3 \\
23.1 \\
\end{array}$ \\
\hline $\begin{array}{l}1 \\
2 \\
3 \\
4 \\
\mathrm{x}\end{array}$ & $\begin{array}{c}600 \\
282 \\
26 \\
29 \\
1\end{array}$ & $\begin{array}{l}64,0 \\
30.1 \\
2.8 \\
3.1 \\
0.1\end{array}$ & $\begin{array}{c}64,0 \\
30.1 \\
2.8 \\
3.1\end{array}$ \\
\hline $\begin{array}{r}\mathrm{pN} \\
0, \text { ITC, 1MIC } \\
1,2,3 \\
\text { Unknown }\end{array}$ & $\begin{array}{l}508 \\
311 \\
119\end{array}$ & $\begin{array}{l}54.2 \\
33.2 \\
12.7\end{array}$ & $\begin{array}{l}62.0 \\
38.0\end{array}$ \\
\hline $\begin{array}{r}\text { Type of surgery } \\
\text { Mastectomy } \\
\text { Conservative }\end{array}$ & $\begin{array}{l}255 \\
683\end{array}$ & $\begin{array}{l}27.2 \\
72.8\end{array}$ & $\begin{array}{l}27.2 \\
72.8\end{array}$ \\
\hline Vascular invasion & $\begin{array}{l}429 \\
509 \\
\end{array}$ & $\begin{array}{l}45.7 \\
54.2 \\
\end{array}$ & $\begin{array}{l}45.7 \\
54.2 \\
\end{array}$ \\
\hline Radiotherapy & $\begin{array}{l}258 \\
680\end{array}$ & $\begin{array}{l}27.5 \\
72.5\end{array}$ & $\begin{array}{l}27.5 \\
72.5\end{array}$ \\
\hline Chemotherapy & $\begin{array}{l}548 \\
390\end{array}$ & $\begin{array}{l}58.4 \\
41.6\end{array}$ & $\begin{array}{l}58.4 \\
41.6\end{array}$ \\
\hline $\begin{array}{r}\text { Type of endocrine therapy } \\
\text { Tamoxifen } \\
\text { Switch } \\
\text { Aromatase Inhibitors }\end{array}$ & $\begin{array}{c}709 \\
180 \\
49 \\
\end{array}$ & $\begin{array}{c}75.5 \\
19.1 \\
5.2\end{array}$ & $\begin{array}{c}75.5 \\
19.1 \\
5.2\end{array}$ \\
\hline $\begin{array}{r}\text { Type of chemotherapy } \\
\text { CMF } \\
\text { Anthracycline } \\
\text { FEC or CMF+FEC } \\
\text { Taxanes or Vinorelbine }\end{array}$ & $\begin{array}{c}112 \\
66 \\
116 \\
96\end{array}$ & $\begin{array}{l}28.7 \\
16.9 \\
29.7 \\
24.6\end{array}$ & $\begin{array}{l}28.7 \\
16.9 \\
29.7 \\
24.6\end{array}$ \\
\hline
\end{tabular}

ITC isolated tumor cells; MIC micrometastasis; $C M F$ cyclophosphamide, methotrexate and fluorouracil; FEC fluorouracil, epirubicin and cyclophosphamide 
Table 2 Patients' and histopathological characteristics according to androgen receptor status

\begin{tabular}{|c|c|c|c|c|}
\hline Characteristics & $\begin{array}{c}\text { AR } \\
\text { negative }\end{array}$ & $\begin{array}{c}\mathrm{AR} \\
\text { positive }\end{array}$ & $\chi^{2}$ & $P$-value \\
\hline $\begin{aligned} \text { Age } & \leq 40 \text { years } \\
& 40-70 \text { years } \\
& \geq 70 \text { years }\end{aligned}$ & $\begin{array}{c}6 \\
194 \\
50 \\
\end{array}$ & $\begin{array}{c}23 \\
460 \\
126 \\
\end{array}$ & 1.336 & 0.567 \\
\hline $\begin{array}{l}\text { Histotype } \\
\text { Ductal and Lobular } \\
\text { Special types }\end{array}$ & $\begin{array}{c}163 \\
87 \\
\end{array}$ & $\begin{array}{l}419 \\
190 \\
\end{array}$ & 0.894 & 0.335 \\
\hline $\begin{array}{r}\text { Grade } \\
\text { Low } \\
\text { Intermediate } \\
\text { High } \\
\end{array}$ & $\begin{array}{c}82 \\
102 \\
66 \\
\end{array}$ & $\begin{array}{l}201 \\
277 \\
131 \\
\end{array}$ & 2.731 & 0.255 \\
\hline $\begin{array}{l}1 \\
2 \\
3 \\
4\end{array}$ & $\begin{array}{c}147 \\
79 \\
9 \\
14 \\
\end{array}$ & $\begin{array}{c}394 \\
186 \\
16 \\
13 \\
\end{array}$ & 8.42 & 0.038 \\
\hline $\begin{array}{r}\mathrm{pN} \\
0, \text { ITC, } 1 \mathrm{MIC} \\
1,2,3 \\
\end{array}$ & $\begin{array}{l}115 \\
101\end{array}$ & $\begin{array}{l}347 \\
186 \\
\end{array}$ & 8.656 & 0.003 \\
\hline $\begin{array}{rr}\text { Vascular invasion } & \\
& \\
& \text { No } \\
\text { Yes } \\
\end{array}$ & $\begin{array}{l}109 \\
141 \\
\end{array}$ & $\begin{array}{l}275 \\
334 \\
\end{array}$ & 0.116 & 0.733 \\
\hline PgR status & $\begin{array}{c}65 \\
185 \\
\end{array}$ & $\begin{array}{l}114 \\
495 \\
\end{array}$ & 5.263 & 0.022 \\
\hline $\begin{array}{l} \\
\leq 10 \% \\
>10 \%\end{array}$ & $\begin{array}{c}91 \\
117 \\
\end{array}$ & $\begin{array}{l}257 \\
272 \\
\end{array}$ & 1.212 & 0.271 \\
\hline $\begin{array}{l}\text { Negative } \\
\text { Positive }\end{array}$ & $\begin{array}{c}221 \\
26 \\
\end{array}$ & $\begin{array}{c}525 \\
74 \\
\end{array}$ & 1.791 & 0.408 \\
\hline
\end{tabular}

$A R$ Androgen Receptor; ITC isolated tumor cells; MIC micrometastasis; $P g R$ Progesterone Receptor, HER 2 human epidermal growth factor receptor 2.

Table 3. Univariate analysis of clinical and pathological data correlated with time to relapse. 


\begin{tabular}{|c|c|c|c|c|c|c|c|c|c|}
\hline & \multicolumn{3}{|c|}{ General } & \multicolumn{3}{|c|}{ Endocrine therapy } & \multicolumn{3}{|c|}{ Endocrine and chemotherapy } \\
\hline & $\begin{array}{c}\% \\
\text { Censored }\end{array}$ & $\begin{array}{c}\text { CPS } \\
\text { at } 10 \\
\text { years } \\
\text { (range } \\
0-1)\end{array}$ & $\begin{array}{c}P- \\
\text { value }\end{array}$ & $\begin{array}{c}\% \\
\text { Censored }\end{array}$ & $\begin{array}{c}C P S \\
\text { at } 10 \\
\text { years } \\
\text { (range } \\
0-1)\end{array}$ & $\begin{array}{c}P- \\
\text { value }\end{array}$ & $\begin{array}{c}\% \\
\text { Censored }\end{array}$ & $\begin{array}{c}\text { CPS } \\
\text { at } 10 \\
\text { years } \\
\text { (range } \\
0-1)\end{array}$ & $\begin{array}{c}P- \\
\text { value }\end{array}$ \\
\hline Age (years) & & & & & Trange & & & Thange & \\
\hline$\leq 4 b$ & 80.6 & 0.82 & \multirow{3}{*}{0.002} & 80 & n.d. & \multirow{3}{*}{0.008} & 80.8 & 0.83 & \multirow{3}{*}{0.003} \\
\hline A 4070 & 93.7 & 0.89 & & 95.8 & 0.93 & & 91.4 & 0.85 & \\
\hline$=47$ & 90 & 0.77 & & 92.1 & 0.79 & & 76.9 & n.d. & \\
\hline$>70$ & 884 & $\overline{081}$ & & 915 & 083 & & 692 & $n d$ & \\
\hline 0, ite, lmit- & 96.1 & 0.92 & \multirow{2}{*}{$<0.001$} & 95.8 & 0.92 & \multirow{2}{*}{$<0.001$} & 96.9 & 0.90 & \multirow{2}{*}{0.005} \\
\hline 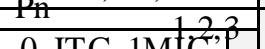 & 84.9 & 0.78 & & 81.7 & 0.72 & & 85.7 & 0.80 & \\
\hline Ype of sutgenty & & $\frac{\sigma}{66}$ & 0.001 & & & 0.006 & & & 0.001 \\
\hline Mastectomy & $\frac{716}{96}$ & 6. & \multirow{2}{*}{$<0.001$} & 97 & 0.77 & \multirow{2}{*}{$<0.001$} & 790 & 0.62 & \multirow{2}{*}{0.002} \\
\hline 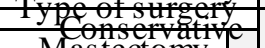 & 83.1 & 0.77 & & 84.4 & 0.80 & & 82 & 0.74 & \\
\hline 作 & 715 & \begin{tabular}{|l|}
.05 \\
068
\end{tabular} & 0.001 & 89 & $\Omega 78$ & $<0.001$ & 660 & 057 & \\
\hline Histotype & 91.1 & 0.85 & \multirow{2}{*}{0.037} & 92.3 & 0.87 & \multirow{2}{*}{0.011} & 89.7 & 0.82 & \multirow{2}{*}{0.954} \\
\hline $\begin{array}{l}\text { Puetalind } \\
\text { Specraltypes }\end{array}$ & 95.7 & 0.93 & & 98.1 & 0.97 & & 90 & 0.85 & \\
\hline \multirow{4}{*}{\begin{tabular}{|l|} 
Grade \\
Spectal types \\
Grate- \\
\end{tabular}} & & & \multirow{4}{*}{$<0.001$} & & & & & & \\
\hline & 96.8 & 0.93 & & 97.4 & 0.98 & \multirow{3}{*}{0.002} & 92.6 & 0.78 & \multirow{3}{*}{0.005} \\
\hline & 93.8 & 0.89 & & 93.7 & 0.88 & & 93.9 & 0.91 & \\
\hline & 83.9 & 0.76 & & 85.1 & 0.79 & & 83.3 & 0.75 & \\
\hline $\mathrm{pT}$ & $\frac{50 .}{71}$ & $\begin{array}{ll}.00 \\
0.62\end{array}$ & \multirow{5}{*}{$<0.001$} & 82 & 0.07 & & & $\frac{0.11}{0.55}$ & \\
\hline प1 & 96.3 & 0.92 & & 97.2 & 0.94 & \multirow{4}{*}{$<0.001$} & 94.3 & 0.91 & \multirow{4}{*}{0.007} \\
\hline & 87.9 & 0.77 & & 87.6 & 0.77 & & 88.1 & 0.75 & \\
\hline & 73.1 & 0.64 & & 66.7 & n.d. & & 76.5 & 0.72 & \\
\hline $\begin{array}{ll}2 \\
2\end{array}$ & 75.9 & 0.78 & & 80 & n.d. & & 73.7 & 0.78 & \\
\hline Vasemlar invas & $\frac{75.1}{517}$ & \begin{tabular}{l|l|}
.11 \\
0.12
\end{tabular} & \multirow[b]{3}{*}{$<0.001$} & & d & & 47 & 017 & \\
\hline No & 97.4 & 0.94 & & 97.6 & 0.95 & & 96.7 & 0.92 & \\
\hline Vascular in tesio & 88.4 & 0.82 & & 89.5 & 0.83 & $<0.001$ & 87.7 & 0.80 & 0.018 \\
\hline Padiotheryou & דיה & | & 0.001 & 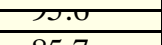 & 每 & $<0.001$ & $\frac{7.0}{0.7}$ & 0.0 & 0.066 \\
\hline 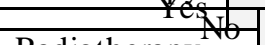 & 87.2 & 0.90 & 000 & 88.1 & 0.93 & 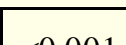 & 86.3 & 0.76 & 0104 \\
\hline Katlotherapyes & 94.5 & 0.80 & 0.001 & 96.6 & 0.84 & $<0.001$ & 91.3 & 0.87 & 0.184 \\
\hline \begin{tabular}{l|l} 
Non & - \\
Yes
\end{tabular} & 888 & \begin{tabular}{l|l|}
.12 \\
081
\end{tabular} & 0.001 & 037 & 080 & 0.004 & 81 & (71 & 0.097 \\
\hline$\theta$ & 93.4 & 0.81 & 0010 & 93 & 0.91 & & 85.4 & 0.71 & \\
\hline 29 & 89.5 & 0.88 & 0.019 & 95.1 & 0.92 & 0.250 & 91.2 & 0.86 & 0.037 \\
\hline HER2 & $\frac{\frac{0 J, 0}{26,7}}{267}$ & \begin{tabular}{|l|l|}
, 10 \\
78
\end{tabular} & 0.469 & & $\frac{0.91}{0.07}$ & 0.826 & 7 & 0,0 & 0.611 \\
\hline$\longrightarrow$ Net & 93 & 0.87 & & 94.4 & 0.89 & & 90.8 & 0.83 & \\
\hline HER2 POS & 90.1 & 0.89 & 0.176 & 96 & 0.95 & 0.654 & 85.2 & 0.84 & 0.064 \\
\hline $\begin{array}{lll}A R & \text { Aleg }\end{array}$ & $\frac{01.4}{70.2}$ & \begin{tabular}{|l|l|}
.17 \\
0.72
\end{tabular} & 0.011 & & 0.01 & & or & 0.70 & 0.013 \\
\hline $\operatorname{Pos} 6$ & 86.4 & 0.78 & 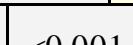 & 92.7 & 0.83 & & 78.8 & 0.72 & \\
\hline$\rightarrow 19$ & 95.2 & 0.92 & $<0.001$ & 95.5 & 0.93 & 0.247 & 94.8 & 0.89 & $<0.001$ \\
\hline $\mathrm{KH}+67$ & $\frac{00}{002}$ & | & 0.001 & 3 & 0.10 & 0.046 & & 0.00 & 0.015 \\
\hline $\begin{array}{ll}319 \\
0\end{array}$ & 97.3 & 0.95 & 0002 & 98.4 & 0.96 & (2000 & 95.1 & 0.92 & \\
\hline$\rightarrow 19$ & 86.7 & 0.85 & 0.002 & 87.3 & 0.80 & 0.002 & 86.1 & 0.80 & 0.178 \\
\hline$>1 \%$ & 74.1 & 0.60 & 0.001 & 80.3 & 0.74 & $<0.001$ & 68.2 & 0.45 & 0.007 \\
\hline
\end{tabular}

CPS Cumulative Proportion Surviving; $n . d$. not done; ITC isolated tumor cells; $M I C$ micrometastasis, $P g R$ Progesterone Receptor; $H E R 2$ human epidermal growth factor receptor 2; $A R$ Androgen Receptor.

Table 4 Univariate analys is of clinical and pathological data corre lated with disease specific survival 
CPS Cumulative Proportion Surviving; $n . d$. not done; ITC isolated tumor cells; $M I C$ mic rometastasis, $P g R$ Progesterone Receptor; HER2 human epidermal growth factor receptor 2; AR Androgen Receptor.

Table 5 Association of patient and tumor characteristics with time to relapse and disease specific survival among all patients with complete data for all covariates.

\begin{tabular}{lcccccccc} 
& \multicolumn{4}{c}{ Time to relapse } & \multicolumn{3}{c}{ Disease specific survival } \\
& HR & $95 \%$ CI & $\chi^{2}$ & P-value & HR & $95 \%$ CI & $\chi^{2}$ & $P$-value \\
Age & 0.390 & $0.232-{ }^{\circ} 0.656$ & 12.580 & 0.000 & 0.356 & $0.163-0.777$ & 6.729 & 0.009 \\
pN & 1.599 & $0.919-2.780$ & 2.762 & 0.097 & 1.747 & $0.749-4.075$ & 1.670 & 0.196 \\
Type of surgery & 1.927 & $1.039-3.574$ & 4.329 & 0.037 & 2.328 & $0.954-5.681$ & 3.446 & 0.063 \\
Histotype & 1.435 & $0.888-2.319$ & 2.177 & 0.140 & 1.360 & $0.652-2.836$ & 0.673 & 0.412 \\
Grade & 1.385 & $0.966-1.986$ & 3.136 & 0.077 & 1.329 & $0.806-2.192$ & 1.246 & 0.264 \\
pT & 1.727 & $1.328-2.246$ & 16.654 & 0.000 & 2.089 & $1.455-2.999$ & 15.935 & 0.000 \\
Vascular Invasion & 2.393 & $1.326-4.318$ & 8.388 & 0.004 & 4.699 & $1.812-12.182$ & 10.133 & 0.001 \\
Radiotherapy & 0.924 & $0.515-1.656$ & 0.071 & 0.790 & 0.927 & $0.416-2.064$ & 0.035 & 0.852 \\
Chemotherapy & 0.928 & $0.531-1.623$ & 0.068 & 0.794 & 0.399 & $0.187-0.854$ & 5.595 & 0.018 \\
PgR & 0.600 & $0.356-1.013$ & 3.658 & 0.056 & 0.308 & $0.156-0.609$ & 11.474 & 0.001 \\
HER2 & 1.887 & $1.109-3.212$ & 5.474 & 0.019 & 1.961 & $0.893-4.303$ & 2.817 & 0.093 \\
AR & 0.458 & $0.296-0.710$ & 12.175 & 0.000 & 0.259 & $0.139-0.482$ & 18.184 & 0.000 \\
KI67 & 2.234 & $1.297-3.848$ & 8.394 & 0.004 & 1.686 & $0.790-3.597$ & 1.826 & 0.177
\end{tabular}

$H R$ Hazard Ratio; $C I$ Confidence Interval; $P g R$ Progesterone Receptor, $H E R 2$ human epidermal growth factor receptor 2; $A R$ Androgen Receptor.

Table 6 Association of patient and tumor characteristics with time to relapse and disease specific survival among patients treated by endocrine therapy with complete data for all covariates 
PATIENTS TREATED BY ENDOCRINE THERAPY

\begin{tabular}{lcccccccc} 
& \multicolumn{4}{c}{ Time to relapse } & \multicolumn{4}{c}{ Disease specific survival } \\
& HR & $95 \%$ CI & $\chi^{2}$ & P-value & HR & $95 \%$ CI & $\chi^{2}$ & P-value \\
Age & 0.241 & $0.091-0.642$ & 8.102 & 0.004 & 0.399 & $0.111-1.426$ & 2.000 & 0.157 \\
pN & 1.925 & $0.658-5.626$ & 1.431 & 0.232 & 1.877 & $0.544-6.472$ & 0.993 & 0.319 \\
Type of surgery & 2.161 & $0.613-7.624$ & 1.435 & 0.231 & 3.263 & $0.751-14.188$ & 2.488 & 0.115 \\
Histotype & 1.718 & $0.677-4.364$ & 1.297 & 0.255 & 0.968 & $0.251-3.726$ & 0.002 & 0.962 \\
Grade & 0.918 & $0.518-1.629$ & 0.085 & 0.771 & 1.038 & $0.498-2.166$ & 0.010 & 0.921 \\
pT & 1.838 & $1.079-3.131$ & 5.023 & 0.025 & 2.410 & $1.285-4.522$ & 7.508 & 0.006 \\
Vascular Invasion & 3.738 & $1.367-10.221$ & 6.599 & 0.010 & 3.564 & $0.946-13.423$ & 3.527 & 0.060 \\
Radiotherapy & 0.596 & $0.176-2.022$ & 0.689 & 0.407 & 0.934 & $0.238-3.664$ & 0.009 & 0.922 \\
PGR & 1.042 & $0.355-3.063$ & 0.006 & 0.940 & 0.506 & $0.150-1.703$ & 1.210 & 0.271 \\
HER2 & 0.912 & $0.234-3.553$ & 0.018 & 0.894 & 0.741 & $0.143-3.855$ & 0.127 & 0.722 \\
AR & 0.427 & $0.190-0.959$ & 4.246 & 0.039 & 0.413 & $0.150-1.137$ & 2.928 & 0.087 \\
KI67 & 2.684 & $0.969-7.438$ & 3.604 & 0.058 & 1.566 & $0.477-5.142$ & 0.546 & 0.460
\end{tabular}

$H R$ Hazard Ratio; CI Confidence Interval; $P g R$ Progesterone Receptor, HER2 human epidermal growth factor receptor 2; $A R$ Androgen Receptor.

Table 7 Association of patient and tumor characteristics with time to relapse and disease specific survival among patients treated by endocrine and chemotherapy with complete data for all covariates

\section{PATIENTS TREATED BY ENDOCRINE AND CHEMOTHERAPY}

\begin{tabular}{|c|c|c|c|c|c|c|c|c|}
\hline & & Time to rela & ose & & & Disease specifi & survival & \\
\hline & HR & $95 \% \mathrm{CI}$ & $\chi^{2}$ & $P$ & HR & $95 \% \mathrm{CI}$ & $\chi^{2}$ & $P$ \\
\hline ge & 0.489 & $0.253-0.947$ & 4.505 & 0.034 & 0.280 & $0.091-0.866$ & 4.881 & 0.027 \\
\hline $\mathrm{N}$ & 1.721 & $0.849-3.486$ & 2.269 & 0.132 & 1.367 & $0.362-5.170$ & 0.213 & 0.645 \\
\hline pe of surgery & 1.990 & $0.966-4.096$ & 3.486 & 0.062 & 1.666 & $0.590-4.706$ & 0.927 & 0.336 \\
\hline is totype & 1.376 & $0.752-2.516$ & 1.074 & 0.300 & 2.353 & $0.853-6.494$ & 2.730 & 0.098 \\
\hline rade & 2.030 & $1.218-3.385$ & 7.372 & 0.007 & 2.281 & $0.978-5.318$ & 3.645 & 0.056 \\
\hline$T$ & 1.625 & $1.190-2.220$ & 9.327 & 0.002 & 2.220 & $1.354-3.641$ & 9.992 & 0.002 \\
\hline Vascular Invasion & 1.969 & $0.914-4.242$ & 2.994 & 0.084 & 11.298 & $1.847-69.091$ & 6.887 & 0.009 \\
\hline Radiotherapy & 1.062 & $0.529-2.131$ & 0.029 & 0.865 & 0.652 & $0.234-1.822$ & 0.664 & 0.415 \\
\hline $\mathrm{R}$ & 0.466 & $0.248-0.878$ & 5.589 & 0.018 & 0.176 & $0.068-0.455$ & 12.883 & 0.000 \\
\hline ER2 & 2.211 & $1.216-4.022$ & 6.758 & 0.009 & 3.022 & $1.138-8.021$ & 4.928 & 0.026 \\
\hline & 0.444 & $0.258-0.765$ & 8.555 & 0.003 & 0.135 & $0.054-0.337$ & 18.339 & 0.000 \\
\hline 67 & 1.842 & $0.958-3.543$ & 3.350 & 0.067 & 1.575 & $0.548-4.526$ & 0.710 & 0.399 \\
\hline
\end{tabular}

$H R$ Hazard Ratio; CI Confidence Interval; $P g R$ Progesterone Receptor, HER2 human epidermal growth factor receptor 2; $A R$ Androgen Receptor. 
Table 8 Association of patient and tumor characteristics with time to relapse and disease specific survival among 343 patients with luminal B cancer with complete data for all covariates

\section{PATIENTS WITH LUMINAL B BREAST CANCER}

\begin{tabular}{lcccccccc} 
& \multicolumn{4}{c}{ Time to relapse } & \multicolumn{5}{c}{ Disease specifc survival } \\
& HR & $95 \% \mathrm{CI}$ & $\chi^{2}$ & P-value & HR & $95 \% \mathrm{CI}$ & $\chi^{2}$ & $P$-value \\
Age & 0.290 & $0.162-0.520$ & 17.242 & 0.000 & 0.354 & $0.148-0.846$ & 0.846 & 0.019 \\
$\mathrm{pN}$ & 1.638 & $0.846-3.169$ & 2.143 & 0.143 & 2.391 & $0.871-6.562$ & 2.864 & 0.091 \\
Type of surgery & 1.763 & $0.810-3.835$ & 2.044 & 0.153 & 2.525 & $0.923-6.905$ & 3.256 & 0.071 \\
Histotype & 1.367 & $0.771-2.425$ & 1.145 & 0.285 & 1.081 & $0.434-2.694$ & 0.028 & 0.867 \\
Grade & 1.197 & $0.791-1.810$ & 0.724 & 0.395 & 1.130 & $0.625-2.043$ & 0.163 & 0.686 \\
pT & 1.826 & $1.367-2.439$ & 16.595 & 0.000 & 2.008 & $1.339-3.011$ & 11.377 & 0.001 \\
Vascular Invasion & 2.203 & $1.093-4.438$ & 4.884 & 0.027 & 6.836 & $1.737-26.908$ & 7.560 & 0.006 \\
Radiotherapy & 0.753 & $0.353-1.607$ & 0.539 & 0.463 & 1.009 & $0.395-2.581$ & 0.000 & 0.985 \\
Chemotherapy & 0.780 & $0.398-1.530$ & 0.521 & 0.470 & 0.351 & $0.142-0.870$ & 5.114 & 0.024 \\
PgR & 0.712 & $0.381-1.328$ & 1.142 & 0.285 & 0.351 & $0.206-1.066$ & 3.270 & 0.071 \\
AR & 0.521 & $0.306-0.888$ & 5.743 & 0.017 & 0.276 & $0.130-0.588$ & 11.135 & 0.001
\end{tabular}

$H R$ Hazard Ratio; $C I$ Confidence Interval; $P g R$ Progesterone Receptor; AR Androgen Receptor. 